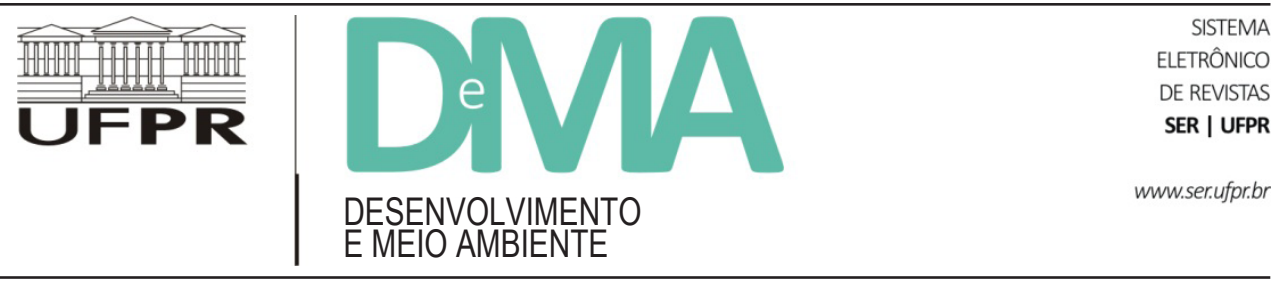

\title{
Climate Change Journalism: From Agony to Agonistic Debate
}

\section{Jornalismo da mudança climática: da agonia ao debate agonístico}

\author{
Yves PEPERMANS ${ }^{1 *}$, Pieter MAESEELE ${ }^{1}$ \\ ${ }^{1}$ Faculty of Social Sciences, University of Antwerp, Belgium. \\ *E-mail of contact: yves.pepermans@uantwerpen.be
}

Article received in November 14, 2016, final version accepted in April 28, 2017.

ABSTRACT: Starting from a politicized outlook on climate change, this essay criticizes mainstream journalistic norms for failing to enable an agonistic, democratic debate about how to move forward. Based on a targeted search for examples from the reporting (and reflection thereof) of two Dutch-speaking alternative news sites (DeWereldMorgen and De Correspondent), we seek to illustrate how their respective (climate) journalists look for truth, generate democratic debate and hold power accountable by combining practices from constructive journalism, slow journalism and advocacy journalism. We find these journalists to focus on patterns, root causes and underlying values, rather than on novelty or exceptional events. Furthermore, an impartial and detached style of reporting is explicitly denounced in favor of an open and reflexive choice of news-making based on advocacy.

Keywords: climate change; journalistic norms; (de-)politicization; objectivity.

RESUMO: A partir de uma visão politizada da mudança climática, este trabalho critica o jornalismo convencional por falhar em promover um debate agonístico e democrático sobre como seguir em frente. Com base em uma busca direcionada por exemplos nas reportagens (e respectiva reflexão) de dois sites de notícia alternativos em língua holandesa (DeWereldMorgen e De Correspondent), nós buscamos ilustrar como seus respectivos jornalistas (do clima) buscam a verdade, geram debate democrático e responsabilizam o poder combinando práticas do jornalismo construtivo, do slow journalism (“jornalismo desacelerado") e da advocacia jornalística. Nós consideramos que esses jornalistas se focam em padrões, causas e valores subjacentes, ao invés de novidades ou eventos excepcionais. Além disso, denuncia-se explicitamente um estilo de comunicação imparcial e neutro em favor de uma escolha aberta e reflexiva de produção de notícias baseada na advocacia.

Palavras-chave: mudança climática; normas jornalísticas; (des-)politização; bjetividade. 


\section{Introduction}

A series of events in 2016 have left climate commentators in agony about the future. Wild fires, diminishing glaciers, coral bleaching and failing harvests have made climate change more tangible than ever, as 2016 replaced 2015 and 2014 as the hottest years on record (WMO, 2017). After the initial enthusiasm about the Paris agreement, the United Nations Environment Program has shown that there is a clear (emission) gap between the optimistic rhetoric of world leaders and the action necessary to ward off runaway climate change (UNEP, 2016). Hope to keep climate change within safe levels for billions of people is further decreased now that electoral majorities in both the United Kingdom and the United States have rejected the earlier cross-party ideological consensus on globalism - the belief that the world will inevitably be a better place through transnational coordination of governance, finance and science, and the free-flow of goods and people-, which in the minds of many also lies behind the science, discourse and policies of climate change (Hulme, 2016). The rise of nationalism and illiberal democracy is accompanied by the rise of lies about political opponents disguised as journalism, and increased attacks on and threats to critical journalists for being "fake news" or "the opposition party". In true Orwellian style, government agencies such as the Environmental Protection Agency in the US have been banned from regulating greenhouse gas emissions or even communicate about climate change.

Debate is raging between journalists, editors and academics over how to deal with these events. Some plead for more impartiality and fact-checking (Politifact, 2017); others think the solution is to pay less attention to the Trump administration and other climate deniers (Olberman, 2017); still others think journalists should foster dialogue between different ideological bubbles (Dijkgraaf, 2016). This essay wants to engage in this ongoing debate by arguing that only an agonistic approach holds the potential to relieve us from the current agony. The argument proceeds as follows. In the first paragraph, we explain that making both the root causes of climate change and fundamentally alternative sustainable futures subject of debate requires a politicized outlook on the issue, echoing an agonistic view of democracy. The second paragraph zooms in on why mainstream journalistic norms impede such a politicized outlook on climate change. In the third paragraph, two alternative news sites are discussed, focusing on how both rely on alternative journalistic practices in their climate reporting, that can be characterized as forms of constructive journalism, slow journalism or advocacy journalism.

\section{A politicized outlook on climate change}

The intangibility and intractability of climate change makes the issue exceptionally multivalent, enabling a limitless range of self-serving interpretations of causality, timing and impact (Marshall, 2014, p. 95). Previous research has convincingly shown, that both public intellectuals' (e.g. Nisbet, 2014), newspapers' (e.g. Carvalho, 2007) and citizens' (e.g. Kahan, 2012) discourses about climate change are profoundly political. As a cultural idea, climate has consequently been used by societies and movements to carry and promote different ideological projects (Hulme, 2009; 2015). How climate change is believed in or denied, how it is acted upon or resisted, can only be understood at the level of much deeper beliefs people hold about themselves and about how the world is, could and 
should be (Hulme, 2016). Like in a Rorschach test, climate change can also be seen as a policy inkblot, on which people project their hopes and values associated with their vision of what a better world would look like (Pielke, 2011, p. 62). At the same time, mainstream public discourse fails to make the underlying political projects or ideological viewpoints on society (e.g. ecosocialism, communitarianism, green neoliberalism), and their related framings of climate change (e.g. Climate Justice, Transition Towns, Green Economy) subjects of democratic debate (Kenis, 2015, p.184-185). Similarly, Hulme (e.g. 2007) has frequently argued that genuine and necessary debates about wider social values and virtues are avoided or represented as disputes about scientific truth and error (the widespread use of labels such as climate skeptics, denialists or alarmists is a clear illustration of this). When climate change is represented in consensual, managerial and/or technocratic terms, then it is depoliticized, which is problematic since it impedes a broad democratic debate about (alternatives to) the existent societal structures and ways of life that lay at the root of ecological disruptions (Pepermans \& Maeseele, 2014; 2016).

A politicized debate would require shifting the terms of the debate from a focus on scientists' assessments of the physical causes and consequences of climate change to a focus on the societal root causes, the various strategies for change and the existing different visions and alternatives at stake (Jensen, 2002). This transforms climate change into a political issue, as something about which society has capacity for agency and debate in situations of genuine collective or social choice (Hay, 2007).
Hay argues that issues can be politicized, if they are shifted from the realm of necessity to the private sphere, from the private to the public sphere, and from the public to the government sphere. For instance, when one politicizes the links between cattle farming and carnivorous diets on the one hand, and climate change on the other, one shows that climate change is not determined by fate, but by our choices and that the (over-)consumption of meat is not a necessity or a purely individual matter, but a matter of public debate, collective action and policy intervention.

The politicization of climate change is not to be confused with climate deniers' efforts to undermine government regulation by deproblematizing climate change (McCright \& Dunlap, 2011). On the contrary, climate denial should be seen as a symptom of depoliticization, rather than a challenge to it (Goeminne, 2012). Climate deniers raise doubts about the least political aspects of climate change (i.e. scientists' assessments of the physical causes and consequences of climate change), those which are beyond collective, human control and about which hardly any (expert) disagreement exists (Kenis \& Lievens, 2015, p.32-33). By doing this, climate deniers stage a scientific non-debate, while avoiding what is and should be the central topic and source of disagreement: the question of how to (re-) organize society (Kenis \& Lievens, 2015, p. 32-33).

A politicized representation frames complex issues such as climate change neither as "matters of fact", in terms of "true and false", nor as a choice between "matters of values", which retreats to radical relativism by granting every opinion equal value (Van Poecke et al., 2014, p. 2-5). ${ }^{1}$ Debate,

\footnotetext{
${ }^{1}$ We accept the mainstream view in climate science that (i) global temperatures are rising, (ii) anthropogenic activities are the main cause for this and (iii) the negative consequences of climate change outweigh the positive ones (Cook et al., 2013).
} 
conflict or resistance should be seen as a struggle for "matters of concern", i.e. in terms of what (not) to be concerned about and what (not) to take into account (e.g. the rights of people in small island states to a stable environment or the jobs of miners in Poland). This idea of "matters of concern" recognizes that factual claims are inextricably intertwined with diverse images of a desirable world. A politicized epistemology does not deny that there is such a thing as reality or reliable scientific data, but argues that there is always and inevitably a gap between that reality and the representations of it (filled by fantasy, ideology, discourses of power, etc.) (Kunelius, 2012, p. 43).

In other words, a politicized outlook on climate change is required to enable a broad democratic debate about the underlying political project(s) that shape(s) our societies today (and implicate runaway climate change) and about potential alternative political projects (that put us on the road to more sustainable futures). This outlook on climate change corresponds to an agonistic view of democracy. Such a view is different from others, such as liberal or deliberative views, in starting from the assumption that issues such as power, ideology and resistance should not be overcome, but should be made visible, so they can become the subject of democratic discussion, and effective and democratic social change beyond the status quo becomes possible (Carvalho, van Wessel \& Maeseele, 2017; Kenis, 2015; Machin, 2013; Maeseele \& Raeijmaekers, forthcoming; Mouffe, 2005; 2013). Put differently, an agonistic view of democracy foregrounds a logic of contestation, implying that only a (respectful) contestation of existing power arrangements and value systems enables a democratic debate about, and change of alternative power arrangements and value systems.

\section{Mainstream journalistic norms and their problems}

Despite the importance of a politicized outlook on climate change, mainstream journalistic norms impede such an outlook, and by extension, an agonistic democratic debate. Journalistic norms are a set of criteria that journalists and news media use to determine the newsworthiness, interpretation and presentation of an event or story (Hansen, 2010, p. 197). Boykoff \& Boykoff (2007, p. 1192) make an interesting distinction in this regard between firstand second-order journalistic norms. The former refer to the journalistic norms of personalization, novelty and dramatization, while the latter refer to the norms of authority-order and balance. The journalistic norms of personalization, novelty and dramatization are called "first-order" norms as they are regarded as the primary influence on what gets covered and how (Boykoff \& Boykoff, 2007, p.1192). Boykoff (2011, p. 101) criticizes "the inclination of journalists to personalize climate stories as driven by individuals rather than group dynamics or social processes for de-emphasizing issues of power, context, and process and for reducing fundamental ideological disagreements to pitched battles between personalities" (Boykoff, 2011, p. 101). In other words, the personalization norm has profoundly depoliticizing consequences. The novelty norm refers to the tendency of news to be largely event-driven. Already in 1979, Schoenfeld et al. observed that the timescale of most environmental problems like climate change is ill-suited to the 24-hour cycle of news production. Similarly, Ungar (2014) has shown how climate reporting appears to be dependent on dramatic real-world events (e.g. extreme weather events or international summits attended by heads of governments) on 
which it can "piggyback". Such events rarely allow for debate between alternative political strategies and policy programs. The norms novelty and dramatization are largely responsible for the focus in news on negative, extraordinary events, rather than on gradual processes like climate change (Boykoff \& Boykoff, 2007, p.1192). Similarly, Lomborg (2005, p. 34-42) has criticized these norms for turning media discourse on climate change more "emotional", "alarmist" and "exaggerated" than what can be claimed based on climate science. In the end, first-order journalistic norms result in an episodic, rather than thematic, framing of climate change. Thematic framing situates news stories in a larger, thematic context to allow for deeper understandings of political and social issues (Boykoff \& Boykoff, 2007, p. 1192; Iyengar, 1991). These norms can also be characterized as what WWF's Living Planet Reports (2016, p. 88-105) call the first level of thinking. Policy and media discussion remains stuck on events, which represent only the tangible and visible "tip of the iceberg" phenomena within a system. By only paying attention to events, news covers the symptoms but not the sources of a problem. An alternative would be systemic thinking or the "four levels of thinking" model (Maani \& Cavana in WWF, 2016, p. 88). This calls for a reorientation from the current focus of journalists and politicians on events towards a focus on societal trends and patterns in terms of systemic structures and the mental models (i.e. the beliefs, values and assumptions that we personally or collectively hold).

The authority-order and balance norms constitute what Boykoff \& Boykoff (2007) refer to as second-order journalistic norms. They are referred to as second-order, since their implementation is less straightforward: in normal situations, journalists tend to restrict their sources to spokespersons from the most authoritative institutions in society (e.g. government, business, or science), but when there is an overt clash between authorities (e.g. clash between the Trump administration and the IPCC), the balance norm prevails. These two norms underlie the ideal of objectivity, which constitutes the cornerstone of professional journalism's claim to truth. Their implementation is believed to ensure a more or less mimetic representation of society, or put differently, an "authentic" and "truthful" reflection of reality (Raeijmaekers \& Maeseele, 2016, p. 7). Balanced reporting aims to "present the views of legitimate spokespersons of the conflicting sides in any significant dispute and provide both sides with roughly equal attention" (Entman, 1989 , p. 30). Balance is generally also interpreted as impartiality, the idea that these views should be presented "neutrally", or better: depersonalized, detached and rationalized. On the other hand, the norm authority-order could also be interpreted as serving as a short-cut for journalists in implementing the balance norm, as it comes down to relying mainly on views from spokespersons from the most authoritative institutions in society.

As Harbers argues (2016, p. 5), the objectivity norm is based on the modernist assumption that facts and values, detachment and engagement, and neutrality and commitment can be separated in a straightforward fashion, allowing media coverage to be evaluated as either balanced or biased. In other words, what maintains professional journalism's claim to authority and authenticity is the remaining centrality of a universalistic truth claim, or put differently, the idea that a finalized and monolithic representation of reality is possible and within reach. For example, research by Smith (2005, p. 1473 ) has shown that broadcast journalists and editors define their role as neutral intermediaries that ought to mirror what is commonly put forward as 
the established consensus within climate science. In workshops, these newsmakers were found to start from the assumptions of the deficit model of media and science, which holds the media responsible for public ignorance of both causes and consequences of climate change, which, moreover, are only approached in scientific terms. Other research studies have shown how this has resulted in media representations that either explicitly affirm the existence of a scientific consensus on climate change (against any potential climate denialism) or seek a balance between those who affirm a scientific consensus and others who challenge it, depending on the political context of a particular region (Weingart et al., 2000; Dispensa \& Brulle, 2003; Boykoff \& Boykoff, 2007; Antilla, 2010; Dirikx \& Gelders, 2010; Leon \& Erviti, 2011). The latter has generally been criticized by scholars for leading to an informational bias, as it authorizes climate denialists to figure as prominently in the news as climate scientists (Boykoff $\&$ Boykoff, 2007). Furthermore, balancing views about scientific claims has also been shown to produce a conservative bias in favor of the status quo of the fossil fuel economy (Boykoff \& Boykoff, 2007). Other studies point to how journalists' desire to appear objective and impartial potentially serves as a motivation to avoid covering climate change in a way that threatens established interests (Nisbet \& Mooney, 2007; Antilla, 2010).

In the end, we can argue that dominant journalistic norms have profound, negative consequences on the information, debate, and accountability function of news media. Indeed, as the authority-order norm in itself already suggests, neither balance nor impartiality should be regarded as "neutral" or "universal" concepts, since they are interpreted in terms of an assumed consensus regarding which spokespersons or views are relevant or acceptable to the public interest. Moreover, this implies that these norms, as well as the underlying ideal of objectivity, are grounded in a post-ideological view on society that assumes that media should affirmatively reproduce a particular consensus. This stands in opposition to the agonistic logic of contestation that aims at fostering a democratic debate about and beyond the limits of social consensus, instead of within the limits of social consensus (Maeseele \& Raeijmaekers, forthcoming; Raeijmaekers \& Maeseele, 2016).

In the following paragraph, we will show that different journalistic practices are not only possible, but also crucial in building an alternative to climate disruption.

\section{Alternative journalistic norms in DeWereldMorgen and De Correspondent}

The advent of the internet has created many opportunities for new, digital news initiatives to experiment with alternative journalistic practices in response to the deficiencies of mainstream news media and journalistic norms. Two examples in this regard are the Dutch-language news sites DeWereldMorgen and De Correspondent.

DeWereldMorgen (translates as Tomorrow's World) is a non-profit current affairs website that offers a daily mix of news, opinion and blogs. It was founded in 2010 as the heir of two earlier alternative news websites. It is funded by contributions from readers and civil society organizations and by government grants. It operates in Flanders, the Dutch-speaking part of Belgium (population of $6,444,127)$. It does not belong to a commercial media group, rejects commercial advertising and offers its content free of charge. At the time of writing (February 2017), the news outlet is run by a small staff of five professional journalists and 350 
volunteers who write articles, provide photographs and translate texts. Climate change is currently not assigned to a fixed reporter, but has been covered by different journalists in the past, such as the current editor-in-chief Keltoum Berolf. Climate change coverage relies heavily on translated articles from Inter Press Service (IPS), an international alternative news agency which explicitly aims to "give a voice to the voiceless and act as a communication channel that privileges the voices and the concerns of the poorest and creates a climate of understanding, accountability and participation around development, promoting a new international information order between the South and the North." (IPS, 2016). The "about" section reveals that the website reaches 15,000 unique visitors per day, and 400,000 monthly (DeWereldMorgen, 2016). In February 2017, it had 45,926 followers on Facebook, and 11,473 followers on Twitter.

De Correspondent (translates as The Correspondent) is a Dutch journalism platform that focuses on background, analysis, and investigative reporting (The Correspondent, 2017). It aims to bring stories that tend to escape the radar of the mainstream media because by deviating from what is normally understood to be news. It was founded as a crowd-funding initiative in September 2013 by Rob Wijnberg, a former editor of the morning edition of a Dutch leading elite newspaper (NRC Handelsblad), and has since been quickly growing. It is not part of a commercial media group and functions free from advertisements. According to a recent article (Wijnberg \& Smouter, 2016) celebrating the outlets' third anniversary, it is currently funded by 47,000 members and occasional donations, reaching 1.3 million unique visitors per month. It has 161,000 followers on Facebook and 128,000 on Twitter. It employs 44 fulltime contributors (including 18 writing correspondents) and has worked with over
150 freelance writers. Each correspondent has his/ her own focus and specialization. Since May 2015, Jelmer Mommers is their specialized climate \& energy journalist. His mission statement is as follows: "I want to show the impact of climate change and accelerate the transition towards sustainability together with members," and can be read above each article. The Europe correspondent Tomas Vanheste also frequently writes about international and European climate policy. De Correspondent has also published articles by more than 12 guest correspondents about climate change and sustainability related themes.

Both DeWereldMorgen and De Correspondent can be considered as "alternative media" in terms of content, context and production process (Atton, 2002). Although alternative media do not comply to a fixed set of standards, what unites them is their challenge to mainstream media's professionalized and institutionalized practices, in favor of a journalism that pursues an ideal of social responsibility, and rejects the ideal of objectivity with oppositional practices and sometimes even overt advocacy (Atton, 2003, p. 267). In the following sections, our aim is to illustrate how the respective journalists and editors-in-chief of both alternative news outlets characterize their journalistic practices for writing about climate change and reflect about their own role and choices. In doing so, we rely both on examples of articles on climate change and on statements of the respective journalists themselves. About 25 articles were collected from the online archives of the websites of both news outlets and scanned for useful illustrations. It is important to emphasize that we do not claim to have conducted a systematic content analysis. Our results are based on a targeted search for examples that allow us to characterize the nature of the (alternative) journalistic practices by these journalists. 


\section{5. "In a changing climate, news is a weather report"}

In various articles (e.g. Wijnberg, 2016; 2017) and in his book "The News Factory. How media distort our world view" (Wijnberg, (2013), De Correspondent's editor-in-chief argues that mainstream journalism's focus on negative exceptions to the rule makes news inherently conservative. In this way, news creates an aversion towards change, because change is always represented as a sudden, exceptional, and negative disruption to an otherwise benign status quo. He often explicitly focuses on the example of climate change to argue how the issue only rarely prominently features in the news, precisely because it is a structural development, rather than an incidental event:

Since news consists mainly of a series of separate, unrelated events, it grossly neglects developments taking place at a deeper level. Climate change is a good example. If there were no scientists, but only journalists, this slow, invisible, unsensational problem never would have come to our attention. News is about the weather, not the climate (Wijnberg, 2017b).

In this quote, Wijnberg argues how first-order norms make journalists focus, both literally and metaphorically, on the weather rather than climate change. In other words, first-order journalistic norms transform climate change into a second-order issue. This leads to a bias against relevance, rather than to accurate reporting. In its manifest and baseline (also available in English), The Correspondent (2017) states that it wants to be a daily medium focusing on current affairs that aims to be: "Your antidote to the daily news grind". By elaborating on deeper structures and by providing context to societal de- velopments, it aims to shift the focus of news from novelty to relevance, and discuss rules and patterns, rather than the negative exceptions to them.

De Correspondent also targets the dramatization norm for how it leads to an underreporting of solutions and positive trends regarding the production of renewable energy. Leading climate \& energy journalist Jelmer Mommers has published an entire series of articles about the negative effects of the dramatization norm, and has even given a TEDx-Talk (2017a) about the subject, titled "Forget climate Apocalypse. Reasons for hope on a warming planet". In this talk, he argues that the implementation of the dramatization norm by journalists and environmentalists not only leads to a factually inaccurate representation of climate change, but also to counterproductive communication, because it alienates people from the issue and impedes them to take action to mitigate climate change. In his writings, he aims not only at showing the impact of climate change, but also at speeding up the transition towards sustainability by sharing hopeful stories that show that the green revolution is happening and that citizens, businesses and governments (can) shape the future together. In doing so, he frequently links to other articles and documentaries that tell the story of the people leading renewable change and resisting fossil fuels (e.g. a recent article headline: "Trump cannot ruin everything. Five rays of hope for the climate", Mommers, 2017b). Indeed, news coverage that only pays attention to climate change in apocalyptic terms threatens to depoliticize it by concealing the potential for collective agency to mitigate and adapt to climate change, thereby transforming climate disruption into an inevitable fate. To counter this, Mommers frequently focuses on the role of readers as both consumers and citizens to

${ }^{2}$ Quote from an article by Wijnberg (2017a) that problematizes the logic of objectivity. 
push leaders in the public and private sector towards a sustainable future. In that sense, the articles on De Correspondent show that the future is shaped by deliberate, political and therefore conflictual choices. Mommers (2015a) is very clear about this in the lead of his long-read article headlined "Those who want the save the world from its demise, better be silent about the end times" and in which he warns against apocalyptic framing:

There is usually a stony silence in media when it comes to climate disasters. If for once climate change is reported, we immediately find ourselves standing at the edge of a cliff. This has a freezing and paralyzing effect, while what we need is action. Whichever disaster awaits us, it is still our move to make when it comes to our future.

The aim of overcoming the negative bias of mainstream news, through a lens that is more positive and/or solution-focused, is often referred to as "constructive journalism" (Korthagen, 2015). Adepts of constructive journalism acknowledge that media do not just report on issues, but play an active role in transforming society. As a result, they claim it is important to empower audiences in a constructive way by identifying possibilities for action (see also Haagerup, 2014).

Furthermore, it is important to emphasize that episodic framing and "first-order journalistic norms" do not arise out of nowhere, but are symptomatic of particular business models of news. Wijnberg (e.g. 2017a) has frequently argued that as long as news media treat each other as competitors for the latest scoop and remain dependent on advertising revenues, news media will continue as purveyors of human attention. The journalists of DeWereldMorgen share these criticisms of the daily news grind and its event-orientation, and also link it with economic factors such as the effects of commercialization, media policy, the role of private ownership and advertising-dependency. This quote in one of the first articles by the founders of the online news site, Soete \& Barrez (2010), aptly illustrate this perspective:

In recent decades, most media have come into the hands of large corporations. And look, everything that is truly important is snowed under by commercialization. Many crucial social issues hardly or ever reach the existing mass media, and certainly not in a consistent matter. Attention for solutions is even scarcer.

In a recent article following the election of president Trump in the US, one of the current editors-in-chief of DeWereldMorgen, Decreus (2016) sees an increasing occurrence of dramatization, personalization and novelty, which he directly links to the reliance of traditional news media's websites on advertising revenues, and he blames this link for the rise of a "mediatized spectacle democracy" in which the distinction between entertainment and political coverage becomes blurred. He argues how this is successfully exploited by figures like Trump and undermines attention for structural issues like climate change.

\section{6. "Those who claim objectivity always speak the language of power ${ }^{3}$ ?"}

\footnotetext{
${ }^{3}$ This is the title of an interview with De Correspondent co-founder and editor-in-chief Wijnberg by Selslagh (2017) for the Flemish newspaper De Morgen. The title is a quote by Wijnberg in the article.
} 
the editorial board "does not take a standpoint about the news" is therefore, in the first place, the most fundamental deception of your audience... Journalism is not an amoral practice. On the contrary, journalism is moralistic through and through. It's about what we value - or should value - as a society. Therefore, all journalism starts and ends with a view on what is right and what is wrong. That the earth is warming is not news because it is a fact. No, that the earth is warming is news, because it is a bad thing.

In the quote, Wijnberg $(2017 \mathrm{~b}$, italics are by the original author) argues that despite claims to the opposite, the selection and construction of news always starts from what journalists consider to be matters of concern in which values and facts are intertwined. The quote illustrates how climate change is portrayed as a matter of concern, combining factual (e.g. the earth is warming) and value-laden statements (e.g. "it is a bad thing"). By doing so, Wijnberg politicizes both the role of the journalist and the issue of climate change. According to media scholar Harbers (2016), De Correspondent constitutes a clear deviation from the principles of the ideal of objectivity. Its journalism is structured around the mediating subjectivity of its correspondents, who are open and reflexive about their point of view and the journalistic choices they make. This subjectivity, however, is combined with an emphasis on facts, based on in-depth background research regarding a particular issue. Moreover, by being transparent and reflective about the reporting process in the articles themselves, journalism, or the truth for that matter, is no longer represented as a product but as a process in which the writer must convince the reader of his/her arguments. De Correspondent's mission statement explains that it is up to the journalist to decide which side of the story is the most credible and why. Furthermore, the reader is actively encouraged to participate in the reporter's search for truth and accountability by responding below the articles, on the basis of which the articles can subsequently be updated. Harbers (2016, p. 2) concludes that De Correspondent practices a form of "slow journalism...with its emphasis on quality over quantity and speed, societal relevance over current events, on context over bare facts, on participation over consumption, and on professional independence over commercial gain".

DeWereldMorgen on the other hand is more clearly characterized by overt advocacy and opposition to dominant framings of policy issues (Pepermans, 2015; Maeseele et al., 2017). In its mission statement, it is found to reject the notions of objectivity, impartiality and balance, and explicitly chooses to encourage "pluralism" by giving access to those voices of (civil) society, which are neglected by professionalized, commercial media (DeWereldMorgen, 2016). Furthermore, the mission statement argues that neutrality does not exist since the world can only be seen through interpretative frameworks. As a result, its journalists are encouraged to be aware and reflexive of their inevitable subjectivity and assumptions, since being truly objective means revealing, instead of concealing, one's positioning.

In that sense, both DeWereldMorgen and De Correspondent also share characteristics of what Rijssemus (2014) calls advocacy journalism. This form of journalism sees society as characterized by ineradicable conflicts between collective identities, interests, values and perspectives, and openly takes sides with one of these. Advocacy journalism, whether in its informing function, debate function or watchdog function, tries to steer the public debate in a particular direction. To foster agonistic, democratic debate, journalists should be explicit, transparent and open about their ideological positions and show that there are different views and different interpretations (Mouffe in Carpentier \& Cammaerts, 2006, p. 973). By doing so, they create an agonistic 
space where power arrangements and value systems can be challenged and alternative configurations can take shape. Advocacy journalists see it as their task to open the gates of the media to voices and stories that can destabilize the hegemonic way of looking at society or climate change. They do this through a "logic of contestation" as we will show in the next section.

\section{7. "The truth about global warming cannot be found between the positions of the alarmist and skeptic"}

In his plea for good climate journalism, Mommers (2015b) blames the balance norm for contradictory and biased reporting as the quote above shows. He states that most journalists, in their quest for objectivity and fear of activism, think that the opinions of the authoritative players of the fossil economy are more trustworthy than those of the "marginal greens." He argues that this disengages readers and makes them feel powerless and confused. In another article, Mommers (2015c) argues that putting the view of a multinational fossil fuel company like Shell against the position of environmental organizations would make these positions equally valid, which is not the case: "When it comes to drilling in the North pole, Shell is not a credible conversation partner, just like a company that encourages obesity is not a credible source in a story about fat children." He argues that overly neutral reporting about climate change only serves the status quo of the fossil economy, rather than the general interest.

Mommers clearly sides with what he calls the scientific consensus on the anthropogenic nature and the negative effects of climate change, although consciously avoiding alarmism, but he also sides with "the activists of the divestment movement" (Mommers, 2015d); with "the citizens who are uniting in cooperatives to revolutionize the energy supply" (Mommers, 2014); with "the lawyers and judges that contribute to the mitigation of climate change" (Mommers, 2015e); and with "the world wide movement for climate justice" (Mommers, 2015f). In this sense, Mommers clearly starts from the logic of contestation to enable an agonistic democratic debate about climate change. This logic is also very clear in the following quote from an article on DeWereldMorgen, by Lievens (2012), who aptly symbolizes the discursive construction of the climate debate in DeWereldMorgen:

Climate change will increasingly become the social issue of the 21 th century. If we want change, we will have to organize from the bottom-up, instead of letting us be put off by the impasse the global elites have put the climate negotiations in.

In this quote, a clear "us/them" positioning is articulated, in which the journalist takes sides with the grassroots organizations rather than the "global elites", who are often expected to save us from climate catastrophe. This logic of contestation features throughout the coverage of the news outlet. A critical discourse analysis of the coverage of the COP 18 in DeWereldMorgen (Pepermans, 2015) showed how the negotiations were framed as a struggle between alternative policy frameworks (and the alternative sustainable futures or politico-economic projects related to these). Most articles on the website openly took sides with actors who called for more government intervention to regulate the

\footnotetext{
${ }^{4}$ This quote comes from an article by climate journalist Mommers (2015) where he reflects on his journalistic choices and the impossibility of taking an objective position in the climate change debate.
} 
bads and distribute the goods of economic growth to protect the worlds' poor first and foremost. In their writings, journalists were found to reveal, name and problematize the ideological choices and power relations that shape the disagreements at the climate summits. They were found to give voice to the alternative views of civil society, governments of developing countries as well as activists. Furthermore, collective and political contestation by citizens through direct actions, sit-ins and demonstrations was normalized throughout the coverage.

It needs to be emphasized however that advocacy journalism and the logic of contestation does not mean that a journalist cannot act as an "honest broker" who expands the range of technological options and policy choices considered by decision-makers and the public (Pielke, 2007; Nisbet \& Fahy, 2014). Both alternative news outlets expand ideological pluralism by opening the gates to voices and ideas neglected by mainstream media. For example, the pages of De Correspondent are also open to voices that frame climate change differently. De Correspondent aims to increase mutual understanding, and bring readers in contact with different points of view. For instance, in the "Shell Dialogues", employees of the Dutch fossil fuel company Shell are interviewed by Mommers (2016) on how they cope with the idea of climate change while working for a business that plays a huge role in sustaining the problem. This series of articles starts with the article "Dear Shell employees, let's talk" in which Mommers (2016) observes that the voices of those who know the energy system best (employees of the fossil fuel sector) are not being heard and that the greens and the fossil fuel sector lack a common language. He wants both separated camps to talk more and better: "for new insights and more mutual understanding, and maybe a quicker or better coordinated transition towards sustainability". Mommers has also invited a guest correspondent on eco-modernism, Hidde Boersma, who challenges the frames and policy solutions of the environmental movement and ecological activists in several articles (see also Nisbet, 2014).

\section{Conclusion: "You can't be neutral on a moving train"}

This article has argued that mainstream journalistic norms constitute a barrier to the functions of news media as providers of information, arenas for public debate as well as watchdogs of power. Indeed, the problem of the aforementioned journalistic norms goes deeper than misinformation or a lack of accuracy. It is not just that the "purse is mightier than the pen" as advocacy journalist Monbiot (2016) recently suggested. The problem lies in our ideals and assumptions of what news is and how it should be. The focus on negative, personalized events of traditional news, as well as its pretense of objectivity, closes the space for a much needed democratic debate about (alternatives to) the existent societal structures and ways of life which lay at the root of ecological disruptions.

This article not only criticized what Boykoff \& Boykoff (2007) call first- and second-order journalistic norms, but it also delved into the question of how journalists can help create a better climate change debate. Three alternative journalistic practices, i.e. constructive journalism, slow journalism and advocacy journalism, were found to be developed and implemented by (climate) journalists of the two Dutch-speaking alternative media $D e$ WereldMorgen and De Correspondent. These journalists were found to defy the journalistic norms of

\footnotetext{
${ }^{5}$ A quote by Howard Zinn, American historian, which opens the Facebook page of DeWereldMorgen.
} 
dramatization, novelty and personalization, thereby allowing for a systemic and thematic framing of climate change in their articles. Furthermore, they were also found to explicitly challenge the objectivity ideal, through a logic of contestation and by being transparent and reflexive about their journalistic choices and engagement with climate change. By doing so, they aim to transform journalistic norms in accordance with the all-encompassing and transcendent features of the climate issue, rather than finding ways to insert the climate issue into existing journalistic norms (Berglez, 2011, p. 454).

The possible downside of such online alternative media is that they result in fragmentation, inhibiting communication between different discourses and collective identities, while readers retreat in their own truth bubbles. Mouffe already warned against the centrifugal effects of the "internet that perversely allows people to just live in their little worlds" (Cammaerts \& Carpentier, 2006, p. 969), years before the algorithms of Facebook and Google only further increased this type of confirmation bias. The internal focus of some internet communities threatens to impedes antagonistic relations to be translated into agonist ones. Future research needs to examine how people consume and use alternative media such as De Correspondent and DeWereldMorgen (see also Carvalho et al., 2017).

Climate change is often described through analogies and metaphors with trains: it starts slowly, but it is awfully hard to stop once it gains a bit of momentum and heads towards the edge of cliff. One hears about the "derailment" of the climate or whether or not climate policies are "on track". This article focused on climate change communicators who refuse to be neutral on this moving train and choose to break the climate silence of the quiet majority of citizens and politicians.

\section{References}

Antilla, L. Self-censorship and science: A geographical review of media coverage of climate tipping points. Public Understanding of Science, 19(2), 240-256, 2010. doi: 10.1177/0963662508094

Atton, C. Alternative Media. London: Sage, 2002.

Atton, C. What is 'alternative' journalism? Journalism, 4(3), 267-272, 2003. doi: 10.1177/14648849030043001

Berglez, P. Inside, Outside, and beyond media logic: journalistic creativity in climate reporting. Media Culture Society, 33(3), 449-465, 2011. doi: 10.1177/0163443710394903

Boykoff, M. Who speaks for the climate? Making sense of media reporting on climate change. Cambridge: Cambridge University Press, 2011.

Boykoff, M.; Boykoff, J. M. Climate change and journalistic norms: A case study of US mass-media coverage. Geoforum, 38, 1190-1204, 2007. doi: 10.1016/j.geoforum.2007.01.008
Carvalho, A. Ideological cultures and media discourses on scientific knowledge: Re-reading news on climate change. Public Understanding of Science? 16(2), 223-243, 2007. doi: 10.1177/0963662506066775

Carvalho, A.; van Wessel, M.; Maeseele, P. Communication Practices and Political Engagement with Climate Change: A Research Agenda. Environmental Communication, 11(1), 2017. doi: $10.1080 / 17524032.2016 .1241815$

Carpentier, N.; Cammaerts, B. Hegemony, democracy, agonism and journalism: an interview with Chantal Mouffe. Journalism Studies, 7(6), 964-975, 2006. doi: 10.1080/14616700600980728

Cook, J.; Nuccitelli, D.; Green, S. A.; Richardson, M.; Winkler, B.; Painting, R.; Way, R.; Jacobs, P.; Skuce, A. Quantifying the consensus on anthropogenic global warming in the scientific literature. Environmental Research Letters, 8(2), 1-7, 2014. doi:10.1088/1748-9326/8/2/024024 
Dirikx, A.; Gelders, D. Ideologies overruled? An explorative study of the link between ideology and climate change reporting in Dutch and French newspapers. Environmental Communication, 4(4), 190-205, 2010. doi:10.1080/17524031003760838

Entman, R. W. Democracy Without Citizens: Media and the Decay of American Politics. Oxford University Press, New York and Oxford, 1989.

Goeminne, G. Lost in translation: Climate denial and the return of the political. Global Environmental Politics, 12(2), 1-8, 2012. doi:10.1162/GLEP_a_00104

Haagerup, U. Constructive News. Why negativity destroys the media and democracy - and how to improve journalism of tomorrow. New York: Innovation Publishing AG, 2014.

Hansen, A. Media, environment and communication. London \& New York: Routledge, 2010.

Harbers, F. Time To Engage. Digital Journalism, 2016. doi: 10.1080/21670811.2015.1124726

Hay, C. Why we hate politics? Cambridge: Polity Press, 2007.

Hulme, M. The Appliance of Science, 2007. Available at: $<$ http://www.theguardian.com/society/2007/mar/14/scienceofclimatechange.climatechange>. Access in: dec. 2014.

Hulme, M. Why we disagree about climate change: Understanding controversy, inaction, and opportunity. Cambridge: Cambridge University Press, 2009.

Hulme, M. Climate and its changes: a cultural appraisal. Geography and Environment, 2015. doi: 10.1002/geo2.5

Hulme, M. Anglophone Political Populism and the Future of Climate Change, 2016. Available at: <http://www.mikehulme.org/anglophone-political-populism-and-the-future-of-climate-change/>. Access in: nov.2016.

Iyengar, S. Framing Responsibility for Political Issues. The Annals of the American Academy of Political and Social Science, 546, 59-70, 1996.

Jensen, B. B. Knowledge, action and pro-environmental behavior. Environmental Education Research, 8, 325-334, 2002. doi: 10.1080/13504620220145474.

Kahan, D. Why we are poles apart on climate change. $\mathrm{Na}$ ture, 488, 255, 2012. doi: 10.1038/488255a
Kenis, A. From individual to collective change and beyond. Ecological citizenship and politicization. Leuven, Belgium, Thesis (PhD in Bioscience Engineering) - KU Leuven, 2015.

Kenis, A.; Lievens, M. The Limits of the Green Economy. From Reinventing Capitalism to Repoliticizing the Present. Milton Park/New York: Routledge, 2015.

Korthagen, I. Wetenschap, journalistiek en medialogica, 2016. Available at: <https://www.rathenau.nl/nl/publicatie/ wetenschap-journalistiek-en-medialogica $>$. Access in: nov. 2016.

Kovach, B.; Rosenstiel, T. The elements of journalism: What news people should know and the public should expect. New York: Crown Publishers, 2007.

Kunelius, R. Varieties of realism: Durban editorials and the discursive landscape of global climate politics. In: Eide, E.; Kunelius, R. (Eds.). Media meets climate: The global challenge for journalism. Götheborg: Nordicom, 2012. p. 31-48.

Leon, B.; Erviti, M. C. Portrayal of scientific controversy on climate change. A study of the coverage of the Copenhagen summit in the Spanish press. Observatorio Journal, 5(3), 45-63, 2011. doi: 1646-5954/ERC123483/2011045

Lomborg, B. The skeptical environmentalist. Cambridge: Cambridge University Press, 2005.

Machin, A. Negotiating climate change: Radical democracy and the illusion of consensus. London: Zed Books, 2013.

Maeseele P.; van der Steen L.; Raeijmaekers D.; Reul R.; Paulussen S. In Flanders Fields: De/politicization and Democratic Debate on a GM Potato Field Trial Controversy in News Media. Environmental Communication, 11(2), 166183, 2017. doi: 10.1080/17524032.2015.1094102

Maeseele, P.; Raeijmaekers, D. Journalism and democracy: towards a sustainable future. In: Olausson, U.; Berglez, P.; Ots, M. (Eds.). What is Sustainable Journalism? Integrating the Environmental, Social, and Economic Challenges of Journalism. Bern: Peter Lang, forthcoming in 2017.

Marshall, G. Don't even think about it. Why our brains are wired to ignore climate change. New York: Bloomsbury, 2014.

McCright, A.; Dunlap, R. Anti-reflexivity. The American Conservative movement's success in undermining climate science and policy. Theory, Culture \& Society, 27(2-3), 100-133, 2010. doi: 10.1177/0263276409356001 
Mouffe, C. On the political. London: Routledge, 2005.

Mouffe, C. Agonistics. Thinking the world politically. London/New York: Verso, 2013.

Nisbet, M. C. Disruptive ideas: public intellectuals and their arguments for action on climate change. WIREs Climate Change, 5(6), 809-823, 2014. doi: 10.1002/wcc.317

Nisbet M.; Fahy, D. The need for knowledge based journalism in politicized science debates. Annals of the Academy of Political and Social Sciences, 658, 223-234, 2015. doi: 10.1177/ 0002716214559887

Nisbet, M.; Mooney, C. Policy Forum Framing Sciences. Science, 316, 56, 2007.

Pepermans, Y. The manufacturing of climate consent. From a depoliticized consensus to politicized debate. Antwerp, Belgium, Thesis ( $\mathrm{PhD}$ in communication studies) - University of Antwerp, 2015. doi: 10.13140/RG.2.2.11443.63527

Pepermans, Y.; Maeseele, P. Democratic debate and mediated discourses on climate change: From consensus to de/ politicization. Environmental Communication, 8(2), 216232, 2014. doi: 10.1080/17524032.2014.906482

Pepermans, Y.; Maeseele, P. The (de-)politicization of climate change: problem or solution? WIREs Climate Change, 7, 478-485, 2016. doi: 10.1002/wcc.405

Pielke, R.J. The climate fix: What scientists and politicians won't tell you about global warming. London: Basic Books, 2011.

Raeijmaekers D.; Maeseele P. In objectivity we trust? Pluralism, consensus and ideology in journalism studies. Journalism, 2016. doi: 10.1177/1464884915614244

Rijssemus, T. Het journalistieke weten. Over de objectiviteit van betrokken journalistiek. Utrecht: Universiteit Utrecht, 2014.

Schoenfeld, A.C.; Meier, R.F.; Griffin, R. J. Constructing a social problem: The press and the environment. Social Problems, 27, 38-61, 1979. doi: 10.2307/800015

Smith, J. Dangerous news: media decision-making about climate change risk. Risk Analysis, 25(6), 1471-1482, 2005. doi: 10.1111/j.1539-6924.2005.00693.x

UNEP. Emissions Gap Report, 2016. Available at: <http:// web.unep.org/emissionsgap/>. Access in: nov. 2016.
Ungar, S. Media context and reporting opportunities on climate change: 2012 versus 1988. Environmental Communication, 8(2), 233-248, 2014. doi: 10.1080/17524032.2014.907193

Van Poeck, K.; Goeminne, G.; Vandenabeele, J. Revisiting the democratic paradox of environmental and sustainability education: sustainability issues as matters of concern. Environmental Education Research, 2014. doi: 10.1080/13504622.2014.966659

Weingart, P.; Engels, A.; Pansegrau, P. Risks of communication: Discourses on climate change in science, politics, and the mass media. Public Understanding of Science, 9(3), 261-283, 2000. doi: 10.1088/0963-6625/9/3/304

WMO. WMO confirms 2016 as hottest year on record, about $1.1^{\circ} \mathrm{C}$ above pre-industrial era, 2017. Available at: $<$ https://public.wmo.int/en/media/press-release/wmo-confirms-2016-hottest-year-record-about- $11 \% \mathrm{C} 2 \% \mathrm{~B} 0 \mathrm{c}$-above-pre-industrial-era $>$. Access in: jan. 2017.

WWF. Living Planet Report 2016. Risk and resilience in a new era. Gland: WWF International, 2016.

\section{Consulted primary sources}

De Correspondent. Manifest, 2013. Available at: <https:// decorrespondent.nl/over>. Access in: nov. 2016.

Decreus, T. Dag één van de strijd tegen president Trump. Don't mourn organize, 2016. Available at: <http://www. dewereldmorgen.be/artikel/2016/11/09/dag-een-van-destrijd-tegen-president-trump-dont-mourn-organize $>$. Access in: nov. 2016.

Dijkgraaf, R. Ieders eigen ideologische zuurstoffles, 2016. Available at: <https://www.nrc.nl/nieuws/2016/09/30/ieders-eigen-ideologische-zuurstoffles-4515443-a1524309>. Access in: feb. 2017

DeWereldMorgen.be. Over DeWereldMorgen.be, 2016. Available at: $<$ http://www.dewereldmorgen.be/info/over-dewereldmorgenbe-faq>. Access in: nov. 2016.

IPS. About us, 2016. Available at: <http://www.ipsnews. net/about-us/>. Access in: nov. 2016.

Lievens, M. Klimaattop in Qatar: Wat valt er te verwachten? 2012 Available at: <http://www.dewereldmorgen. be/artikels/2012/11/21/klimaattop-in-qatar-wat-valt-er-teverwachten>. Access in: feb. 2017. 
Mommers, J. Is het einde van de energierekening in zicht? 2014. Available at: <https://decorrespondent.nl/1555/ishet-einde-van-de-energierekening-in-zicht/317494098295691c1db8>. Access in: nov. 2016.

Mommers, J. Wie de wereld van de ondergang wil redden kan over het einde der tijden best zwijgen, 2015a. Available at: $<$ https://decorrespondent.n1/3622/wie-de-wereld-van-deondergang-wil-redden-kan-over-het-einde-der-tijden-beterzwijgen/739526446318-57501bac>. Access in: nov. 2016.

Mommers, J. Wat vinden jullie goede klimaatjournalistiek? 2015b. Available at: <https://decorrespondent.nl/3631/wat-vinden-jullie-goede-klimaatjournalistiek/741364032739-c09ab418>. Access in: nov. 2016.

Mommers, J. Hebben oliebedrijven in het klimaatdebat altijd recht van spreken? 2015c. Available at: $<$ https://decorrespondent.nl/2843/hebben-oliebedrijven-in-het-klimaatdebat-altijd-recht-van-spreken/580473132767-5f209a26>. Access: in: nov. 2016.

Mommers, J. Dankzij deze activisten werd het klimaatverdrag van Parijs een succes, 2015d. Available at: $<$ https://decorrespondent.nl/3228/dankzij-deze-activisten-werd-het-klimaatverdrag-van-parijs-een-succes/659080996332-01529282>. Access in: nov. 2016.

Mommers, J. Klimaatverandering is een onrecht en daar kunnen rechters wat aan doen. 2015e. Available at: $<$ https:// decorrespondent.nl/2958/klimaatverandering-is-onrechten-daar-kunnen-rechters-wat-aan-doen/6039534037026211d9cc>. Access in: nov. 2016.

Mommers, J. Klimaatverandering vraagt om een wereldwijde volksbeweging, 2015f. Available at: $<$ https://decorrespondent.nl/1831/klimaatverandering-vraagt-om-een-wereldwijde-volksbeweging/373846748539-3c3bbf97>. Access in: nov. 2016.

Mommers, J. Dear Shell employees: Let's talk. 2016 Available at: <https://thecorrespondent.com/4049/dear-shell-employees-lets-talk/446236241-89c4a65a>. Access in: nov. 2016.

Mommers, J. Climate change is not the end of the world. In my TEDx-talk there is reason for hope, 2017a Available at: $<$ https://thecorrespondent.com/5638/climate-change-isnot-the-end-of-the-world-in-my-tedx-talk-theres-reasonfor-hope/1151145804622-1049627f>. Access in: feb. 2017.

Mommers, J. Trump kan niet alles verpesten: vijf lichtpuntjes voor het klimaat, 2017b. Available at: <https://decorrespondent.nl/6123/trump-kan-niet-alles-verpesten-vijf- lichtpuntjes-voor-het-klimaat/1250171295087-02c60314>. Access in: feb. 2017.

Monbiot. The purse is mightier than the pen, 2016. Available at: <http://www.monbiot.com/2016/08/04/the-purse-ismightier-than-the-pen/>. Access in: nov.2016.

Olberman, K. How the media needs to respond to Trump now, 2017. Available at: <https://www.youtube.com/ watch?v=Jxd611QJyPU>. Access in: feb. 2017.

Politifact. Statements about climate change, 2017. Available at: <http://www.politifact.com/subjects/climate-change/>. Access in: feb. 2017.

Selslagh, S. Wie objectief wil zijn, spreekt altijd de taal van de macht, 2016. Available at: <http://www.demorgen.be/ dmselect/-wie-objectief-wil-zijn-spreekt-altijd-de-taal-vande-macht-bc73fc69/>. Access in: feb. 2017.

Soete, H.; Barrez, D. Van wie zijn de media? De media zijn van ons! 2010. Available at: <http://www.dewereldmorgen. be/artikels/2010/11/02/van-wie-zijn-de-media-de-mediazijn-van-ons>. Access in: nov. 2016.

The Correspondent. About our journalism, 2017. Available at: $<$ https://thecorrespondent.com/>. Access in: feb. 2017.

Wijnberg, R. De Nieuwsfabriek. Hoe media ons wereldbeeld vervormen. Amsterdam, De Bezige Bij, 2013.

Wijnberg, R. Waarom complotdenkers gelijk hebben over de media (ook al is van een complot geen sprake), 2016. Available at: $<$ https://decorrespondent.nl/5031/waarom-complotdenkers-gelijk-hebben-over-de-media-ook-al-is-van-een-complot-geen-sprake/1027210809339-ae5626ce>. Access in: nov. 2016.

Wijnberg, R.; Smouter, K. Dit was jaar drie van De Correspondent (met een schuin oog op jaar vier), 2016. Available at: $<$ https://decorrespondent.nl/5307/dit-wasjaar-drie-van-de-correspondent-met-een-schuin-oog-opjaar-vier/1083563459583-ce990cbc>. Access in: nov. 2016.

Wijnberg, R. This is how we can fight Donald Trump's attack on democracy, 2017a. Available at: $<$ https://thecorrespondent. com/6150/this-is-how-we-can-fight-donald-trumps-attackon-democracy/157624500-afd6a4d7>. Access in: Feb. 2017.

Wijnberg, R. Waarom objectieve journalistiek een misleidende en gevaarlijke illusie is, 2017b. Available at: $<$ https://decorrespondent.nl/6073/waarom-objectieve -journalistiek-een-misleidende-en-gevaarlijke-illusie-is/1239962481637-73c005b8>. Access in: Feb. 2017. 